\title{
Randomized, blinded, controlled clinical trial shows no benefit of homeopathic mastitis treatment in dairy cows
}

\author{
Fanny Ebert, ${ }^{*}$ Rudolf Staufenbiel, ${ }^{*}$ Julia Simons, ${ }^{*}$ and Laura Pieper ${ }^{*}{ }^{1}$ \\ ${ }^{*}$ Ruminant and Swine Clinic, and \\ †Institute for Veterinary Epidemiology and Biostatistics, Free University of Berlin, 14163 Berlin, Germany
}

\begin{abstract}
Mastitis is one of the most common diseases in dairy production, and homeopathic remedies have been used increasingly in recent years to treat it. Clinical trials evaluating homeopathy have often been criticized for their inadequate scientific approach. The objective of this triple-blind, randomized controlled trial was to assess the efficacy of homeopathic treatment in bovine clinical mastitis. The study was conducted on a conventionally managed dairy farm between June 2013 and May 2014. Dairy cows with acute mastitis were randomly allocated to homeopathy $(\mathrm{n}=70)$ or placebo $(\mathrm{n}=92)$, for a total of 162 animals. The homeopathic treatment was selected based on clinical symptoms but most commonly consisted of a combination of nosodes with Streptococcinum, Staphylococcinum, Pyrogenium, and Escherichia coli at a potency of 200c. Treatment was administered to cows in the homeopathy group at least once per day for an average of $5 \mathrm{~d}$. The cows in the placebo group were treated similarly, using a placebo preparation instead (lactose globules without active ingredients). If necessary, we also used allopathic drugs (e.g., antibiotics, udder creams, and anti-inflammatory drugs) in both groups. We recorded data relating to the clinical signs of mastitis, treatment, time to recovery, milk yield, somatic cell count at first milk recording after mastitis, and culling. We observed cows for up to $200 \mathrm{~d}$ after clinical recovery. Base-level data did not differ between the homeopathy and placebo groups. Mastitis lasted for an average of $6 \mathrm{~d}$ in both groups. We observed no significant differences in time to recovery, somatic cell count, risk of clinical cure within $14 \mathrm{~d}$ after disease occurrence, mastitis recurrence risk, or culling risk. The results indicated no additional effect of homeopathic treatment compared with placebo. The
\end{abstract}

Received August 1, 2016.

Accepted January 27, 2017.

${ }^{1}$ Corresponding author: laura.pieper@fu-berlin.de advantages or disadvantages of homeopathy should be carefully assessed for individual farms.

Key words: homeopathy, dairy cow, mastitis, clinical trial, placebo

\section{INTRODUCTION}

Mastitis is one of the most important diseases in the dairy industry (Schepers and Dijkhuizen, 1991; Olde Riekerink et al., 2008). It leads to significant economic losses caused by reductions in milk yield (Rajala-Schultz et al., 1999; Zoche-Golob and Spilke, 2013), poor milk quality (Houben et al., 1993; Hortet and Seegers, 1998), increased work load (Kossaibati and Esslemont, 1997), early culling (Rajala-Schultz and Grohn, 1999), and high treatment costs (Lührmann, 2007).

Once an animal affected by mastitis has been identified, eliminating the disease is important. Depending on the etiologic agent, self-cure rates range from low (for Staphylococcus aureus; Grommers et al., 1985) to very high (for coliform bacteria; Craven, 1987). In a retrospective study with milk culture results from 9,007 cases of subclinical mastitis, bacterial cure rates were significantly lower $(68 \%)$ in untreated cows than in cows that received antibiotic treatment $(75 \%)$. However, differences between self-cure and antibiotic treatments were found only for streptococci (including Streptococcus agalactiae) and CNS (Wilson et al., 1999). In a small study on clinical mastitis, clinical and microbiological self-cure risks were 40 and $40 \%$ for streptococci and 67 and $78 \%$ for coliform bacteria, respectively (Roberson et al., 2004). Nevertheless, self-cure is often associated with a longer duration of infection, lower milk yield, and the potential for pathological changes in the mammary gland (Bramley and Dodd, 1984). Antibiotic therapy should be chosen based on the mastitis pathogen and the type of mastitis (Ehinger and Kietzmann, 1998; Linder et al., 2013). In acute and peracute cases of mastitis, immediate antibiotic treatment may be warranted (Craven, 1987). Antibiotic treatment can also be combined with increased milking frequency (Roberson et al., 2004), anti-inflammatory drugs (Fitzpatrick et 
al., 2013), fluid substitution (Roberson, 2012), vaccines (Hogan et al., 1992), cytokines (Erskine et al., 1998), or alternative treatment methods (Busato et al., 2000). If treatment is ineffective in avoiding further losses, the affected animal is often culled to prevent further suffering and the spread of pathogens (Bramley and Dodd, 1984).

In recent decades, alternative treatment methods (Vaarst et al., 2006; Langford et al., 2009), including homeopathy (Hovi and Roderick, 2000), have been used increasingly for mastitis treatment. Producers see advantages in the use of homeopathic remedies to avoid withdrawal periods (Boldyreva, 2003), residues (Enbergs, 1998), or antibiotic resistance (Smith, 2002). Homeopathy was developed by the German physician Samuel Hahnemann (Hahnemann, 1810) and is commonly referred to as complementary or alternative medicine (Institute of Medicine of the National Academies, 2005). Evidence-based, Western medicine is often called allopathic medicine. Samuel Hahnemann's philosophy of homeopathy has 3 principles: (1) "like cures like" (simlia similibus curentur); 2) testing the effect of a homeopathic remedy in healthy individuals ("homeopathic prove"); and (3) the use of potentized remedies. For potentization, the homeopathic remedy is activated via special dilution and shaking (succussion) of the ground substance (plant, mineral, or animal in origin) with a carrier substance (e.g., lactose or ethanol; Vickers and Zollman, 1999; Schmidt, 2008). The more often potentization is performed, the higher the potency of the homeopathic remedy and the lower the concentration of the original substance. Different potency scales are available to describe potentization. Using 1 part ground substance in 10 parts carrier substance represents a potentization of $\mathrm{D} 1$; using 1 part ground substance in 100 parts carrier substance represents a potentization of $\mathrm{C} 1$. Furthermore, taking 1 part D1 substance and mixing it with 10 parts carrier substance will yield a potentization of D2 (Rijnberk and Ramey, 2007).

In the European Union, homeopathic remedies used in food-producing animals may be registered under simplified conditions if the concentration of the active ingredient does not exceed 1:10,000 (potency of D4 or $\mathrm{C} 2$, or higher), the route of administration is described in the European Pharmacopoeia, and the active substance is listed in the Annex of Commission Regulation (EU) No. 37/2010. Veterinary homeopathic remedies with active substances that are not listed that have potencies lower than D4 or C2 (concentrations higher than 1:10,000) require normal approvals (Löscher et al., 2006).

Homeopathic treatment is also associated with some disadvantages. Due to their simplified registration, most homeopathic formulations are marketed without pharmacological, toxicological, or clinical assessment (Löscher and Richter, 2010). Moreover, homeopathy might come with direct (due to the use of toxic substances) and indirect (due to the withholding of effective, conventional treatment) side effects (Posadzki et al., 2012). Although little evidence is available for the benefits of homeopathic treatments, they are preferred over allopathic therapies in organic dairy herds. The EU (EG) organic regulation Nr. 889/2008 states that organic farms should prefer homeopathic and phytotherapeutic treatments over allopathic drugs if their therapeutic efficacy has been proven for the species and disease in question (European Commission, 2008).

Still, scientific evidence on the effectiveness of homeopathy is lacking (Albrecht, 2013). Recent studies in veterinary medicine focused on the difference of the cure risk between the therapy and control groups. While some studies found no effects of homeopathic therapy for mastitis (Hektoen et al., 2004; Werner et al., 2010), other studies showed negative results in the homeopathic group (Garbe, 2003; Varshney and Naresh, 2005), and still others showed positive results (Day, 1986; Merck et al., 1989). A meta-analysis found no significant differences between homeopathic and conventional therapies in veterinary medicine (Mathie and Clausen, 2015). As well, although many of the studies detected no positive effect of homeopathic mastitis therapy in dairy cows, the authors' conclusions were often positive (Garbe, 2003; Varshney and Naresh, 2005; Werner et al., 2010). The authors of the meta-analysis suggested that some authors of randomized controlled clinical trials in veterinary homeopathy overemphasized the positive outcomes (Mathie and Clausen, 2015). Furthermore, many of the studies lacked a proper scientific approach. Only $28 \%$ (84/302) studies using homeopathy in veterinary medicine were randomized and placebo-controlled (Clausen et al., 2013). More evidence-based research is needed in complementary veterinary medicine (Lewith et al., 2000; Mathie and Clausen, 2014).

The objective of this triple-blind, randomized controlled trial was to assess the specific treatment effects of homeopathic mastitis treatment in dairy cows. We expected to find a faster clinical cure, higher clinical cure risk, lower SCC after mastitis cure, and lower mastitis recurrence risk in the homeopathic group compared with the placebo group.

\section{MATERIALS AND METHODS}

\section{General Setting}

The study was conducted between June 2013 and December 2014 on a conventional dairy farm in north- 
Table 1. Inclusion criteria, exclusion criteria, and study removal criteria

\begin{tabular}{lll}
\hline Inclusion criteria & Exclusion criteria & Study removal criteria \\
\hline - First mastitis in study & - Repeated mastitis in study period & - Inappetence \\
- Acute catarrhal or parenchymatous mastitis & - Subclinical mastitis & - Apathy \\
- Mild generalized symptoms & - Lack of generalized symptoms & - Downer cow \\
- Rectal temperature $>39.5^{\circ} \mathrm{C}$ on the first day of mastitis & - Severe generalized symptoms & - Severe comorbidity \\
& - Mastitis after teat injury & - Bloody milk \\
& - Infection with Streptococcus agalactiae & \\
\hline
\end{tabular}

ern Germany. In 2014, the farm had 1,565 milking cows and an average milk yield of $10,300 \mathrm{~kg} / \mathrm{cow}$ per year. The cows were kept in a freestall barn with a slatted floor and rubber mats. Groups were arranged according to DIM and reproductive and health status. Cows with mastitis were kept in a separate group on straw bedding. Cows were milked 3 times per day in a $2 \times$ 30 side-by-side milking parlor. The milking machine was regularly serviced, and milking hygiene included prestripping into a strip-cup, wearing milking gloves, cleaning and disinfection of teats using a single-use cloth, intermediate cleaning of gloves, intermediate disinfection of the milking unit between cows, and use of a specific milking order, milking cows with high SCC and mastitis last. Cows with mastitis were detected during milking by trained milking personnel, and clinical mastitis was defined as a change in milk secretion (e.g., flakes); hardening, redness, or increased temperature of the udder; or a combination thereof. Quarter milk samples were collected using aseptic technique from all 4 quarters of a cow at the onset of clinical mastitis. Milk samples were collected according to German Veterinary Association guidelines (Deutsche Veterinärmedizinische Gesellschaft, 2009) by trained farm personnel using single-use gloves and sterile tubes. Milk samples were refrigerated $\left(4^{\circ} \mathrm{C}\right)$ and sent to the laboratory (Landeskontrollverband Berlin-Brandenburg e.V., Waldsieversdorf, Germany) within 1 to $3 \mathrm{~d}$ for microbiological analysis. The laboratory was accredited according to DIN EN ISO/IEC 17025. The overall prevalence of milk samples (routine and mastitis) that were positive for Strep. agalactiae and Staph. aureus during the study period was $0.7 \%$ and $1.9 \%$, respectively.

\section{Inclusion and Exclusion Criteria}

All cows with mastitis during the study period were assessed for inclusion and exclusion criteria (Table 1). If cows met the inclusion criteria, they were allocated to one of the study groups. Primi- and multiparous cows were included in the study if they had a catarrhal or parenchymatous mastitis with mild generalized symptoms, including a rectal temperature $>39.5^{\circ} \mathrm{C}$ on the first day of the disease, and they were having their first case of mastitis in the study period. Catarrhal mastitis was defined as swelling, increased temperature, hardness, and sometimes pain in the udder quarter, with reduced milk yield containing flakes. Parenchymatous mastitis was identified by more severe clinical symptoms and loss of the secretions' milky appearance (Winter, 2008). Cows were excluded if they had subclinical mastitis (Deutsche Veterinärmedizinische Gesellschaft, 2012), clinical mastitis without generalized symptoms (e.g., fever), blood in the milk, or an infection with Strep. agalactiae. Cows were removed from the trial if they showed signs of inappetence, apathy, or a severe comorbidity.

\section{Study Design}

The study was a triple-blind, randomized, placebocontrolled clinical trial. Between June 2013 and May 2014, cows were enrolled in the study. Following an observation period of $200 \mathrm{~d}$ after clinical cure, data collection ended in December 2014.

Cows meeting the inclusion criteria were randomly assigned to the homeopathic or the placebo group. In this study, the farm personnel caring for the animals, the veterinarians assessing clinical signs, and the statistician analyzing the data were blinded to homeopathic or placebo treatment. Bottles containing homeopathic and placebo globules were obtained from a local pharmacy. For each homeopathic preparation, the corresponding placebo bottle was prepared. Bottles were numbered (odd and even) and named for the homeopathic preparation (e.g., Lachesis C200). Except for the number, homeopathic and placebo bottles were indistinguishable. Starting in June 2013, cows with clinical mastitis meeting the inclusion criteria were assigned to receive globules from bottles with odd or even numbers according to the last digit of their ear tag (Figure 1). At monthly intervals during the study period, assignment of the homeopathic treatment or placebo to odd or even bottle numbers was reversed. At the end of each month, all bottles (empty or not) were collected and new bottles were provided containing new prepara- 


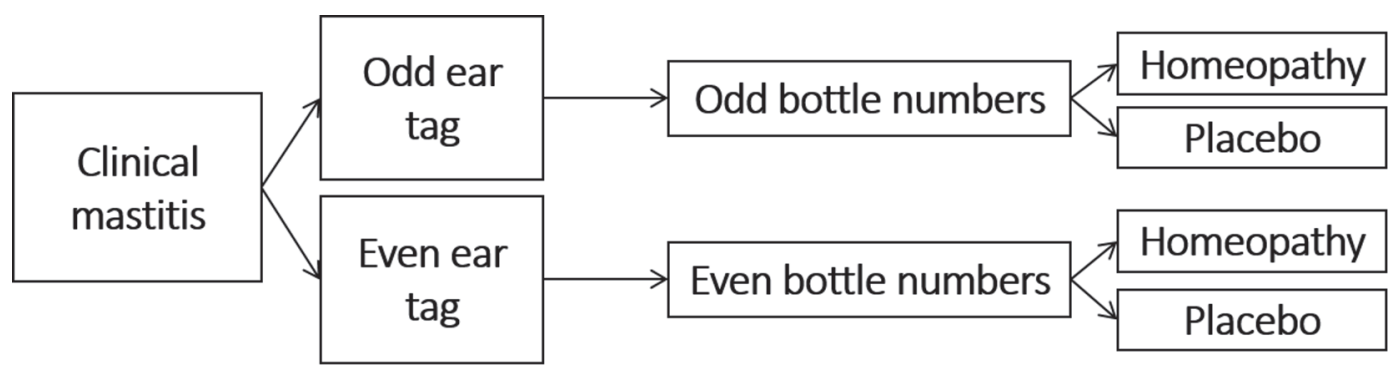

Figure 1. Random allocation of cows to study groups.

tions. It was impossible for assessing veterinarians and farm personnel to identify the homeopathic or placebo status of each cow. We ensured that cows received either homeopathic or placebo globules during the study period, but not both.

Neither the clinical examination measures nor the treatment regimen were changed for this study. All procedures were conducted according to farm protocols and remained consistent throughout the study. The study farm had been using homeopathic remedies for mastitis treatments since 2007.

\section{Clinical Examination}

Following detection of a clinical mastitis case, the cow was examined at least once a day until healing. Healing was defined as good general appearance, the absence of clinical symptoms of mastitis, and physiological milk production (European Medicines Agency, 2013), defined as normal milk without clots or other pathological findings (Dirksen et al., 2012). If the cow's general appearance was moderately impaired, it was examined up to 3 times per day. Examination included measuring of rectal temperature, respiration rate, and milk yield, as well as assessment of appetite, body posture, behavior, milk secretions, and palpable changes in the udder tissue. Poor general appearance was defined as inappetence, depression, sunken eyes, and signs of pain (arched back, bruxism, muscle tremor).

\section{Treatment}

Cows assigned to the homeopathic group received homeopathic treatment based on the rules of clinical homeopathy (Mettler, 1991; Mac Leod and Wolter, 2006; Day and Schmidt, 2008; Gnadl, 2011), and cows in the placebo group received a corresponding placebo. The globules (route of administration, size $0.5-1.5 \mathrm{~mm}$ ) were prepared based on lactose. In the case of the homeopathic globules, these lactose globules were coated with the homeopathic solution. In case of the placebo globules, no homeopathic solution was applied.
One of 8 different homeopathic preparations with a potency of C200, or a combination thereof, was chosen based on clinical signs by a trained veterinarian or a trained veterinary assistant (Table 2). Most commonly, a mixture of 4 nosodes (Escherichia coli-, Pyrogenium-, Staphylococcinum-, and Streptococcinum-nosodes) was given to a maximum of 3 times/d over $5 \mathrm{~d}$. The frequency of application was chosen based on the severity of the clinical symptoms. Other homeopathic remedies (Table 2) were chosen by the veterinarian or veterinary assistant if they did not observe improvement in clinical signs after $5 \mathrm{~d}$. Homeopathic or placebo globules were placed intravaginally (on the mucosal tissue between the labia) 1 to 5 times daily by the veterinarian, veterinary assistant, or trained milking personnel.

Cows from both study groups were eligible to receive additional allopathic treatment (e.g., intramammary or systemic antibiotics, topical udder creams, anti-inflammatory drugs, intravenous fluid therapy), if necessary. Allopathic treatments were selected individually, based on clinical signs and bacteriological findings and according to veterinary protocols.

\section{Sample Size Justification}

The sample sizes of the groups reported in this study were based on a study by Varshney and Naresh (2005), who found a difference in disease duration between the homeopathic group $(7.68 \mathrm{~d} ; \mathrm{SD}=4.83)$ and the control group ( $4.54 \mathrm{~d} ; \mathrm{SD}=1.96)$. A sample size of 38 per group would have been necessary to find this difference, using an $\alpha$ level of 0.05 and a power of $80 \%$. In the present study, we conducted 2 interim analyses (September 2013 and February 2014). The first analysis showed smaller differences in disease duration than the proposed $3 \mathrm{~d}$. Therefore, we increased the sample size to 194 cows.

\section{Statistical Analyses}

We collected data from each study individual, including lactation number and milk yield and diseases in 
Table 2. Homeopathic treatments used in the study

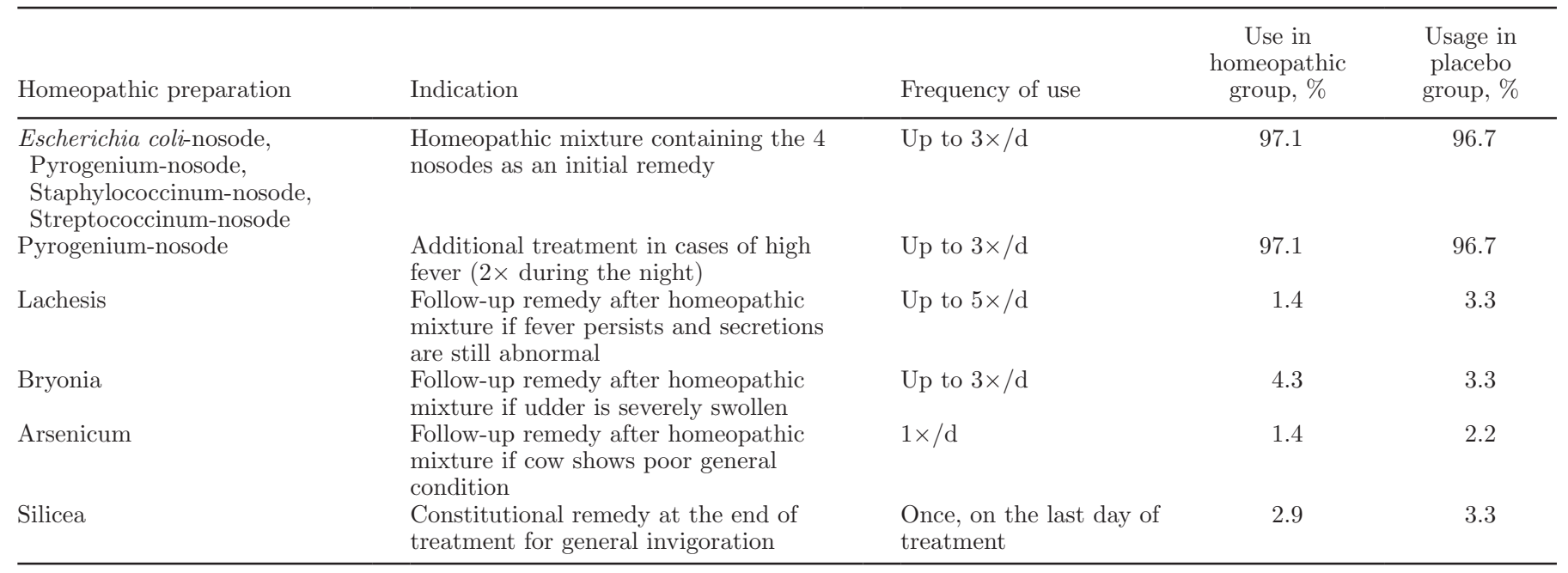

the previous and current lactation. We also recorded the number of affected quarters, the mastitis pathogen, the time to clinical cure, the duration of treatment, the risk of clinical cure, culling, repeated mastitis, and individual cow SCC. Descriptive statistics of the animals are given in Table 3.

The level of analysis was the cow. If a cow had multiple quarters with mastitis, we used the longest time to cure for analysis and measured SCC as a composite of all quarters following milk recording.

We described and checked data for plausibility using descriptive statistics. We assessed normality graphical- ly, using histograms. We displayed metric parameters as median, quartiles, minimum, and maximum. We calculated frequency distribution for ordinal or nominal parameters.

Differences among the 2 study groups in metric data were assessed using Mann-Whitney U-test. For ordinal and nominal data, Chi-squared test or Fisher's exact test was used, where appropriate. Time to clinical cure (disease duration) as well as duration of treatment were compared among groups using Kaplan-Meier survival analysis and log-rank test. Cases were censored if cows were culled before clinical cure. Statistical analyses

Table 3. Descriptive statistics of study animals (categorical parameters)

\begin{tabular}{|c|c|c|c|c|c|}
\hline \multirow[b]{2}{*}{ Parameter } & \multicolumn{2}{|c|}{ Homeopathy } & \multicolumn{2}{|c|}{ Placebo } & \multirow[b]{2}{*}{$P$-value } \\
\hline & No. & $\%$ & No. & $\%$ & \\
\hline \multicolumn{6}{|l|}{ Current lactation } \\
\hline Lactation number & 70 & 100.0 & 92 & 100.0 & 0.559 \\
\hline 1 Lactation & 25 & 35.7 & 37 & 40.2 & \\
\hline$>1$ Lactation & 45 & 64.3 & 55 & 59.8 & \\
\hline Affected quarters & 70 & 100.0 & 91 & 100.0 & 0.839 \\
\hline 1 Quarter & 64 & 91.4 & 84 & 92.3 & \\
\hline$>1$ Quarter & 6 & 8.6 & 7 & 7.7 & \\
\hline Pathogen & 63 & 100.0 & 82 & 100.0 & \\
\hline No pathogen & 15 & 23.8 & 18 & 22.0 & 0.791 \\
\hline Streptococcus uberis & 29 & 46.0 & 32 & 39.0 & 0.397 \\
\hline Escherichia coli & 8 & 12.7 & 15 & 18.3 & 0.361 \\
\hline CNS & 5 & 7.9 & 6 & 7.3 & 1.000 \\
\hline Staphylococcus aureus & 1 & 1.6 & 4 & 4.9 & 0.388 \\
\hline Streptococcus dysgalactiae & 3 & 4.8 & 1 & 1.2 & 0.317 \\
\hline Other pathogens & 1 & 1.6 & 5 & 6.1 & 0.233 \\
\hline Contamination & 1 & 1.6 & 1 & 1.2 & 1.000 \\
\hline \multicolumn{6}{|l|}{ Previous lactation } \\
\hline Mastitis & 69 & 100.0 & 92 & 100.0 & 0.279 \\
\hline Yes & 11 & 15.9 & 21 & 22.8 & \\
\hline Other diseases & 69 & 100.0 & 92 & 100.0 & 0.354 \\
\hline Yes & 60 & 87.0 & 75 & 81.5 & \\
\hline
\end{tabular}


were conducted with the computer program SPSS for Windows (version 22; IBM Corp., Armonk, NY); a $P$ value $<0.05$ was considered significant.

\section{RESULTS}

\section{Study Participants}

A total of 470 cows had a case of mastitis during the study period. Of these, 276 fulfilled at least 1 exclusion criterion (Table 1), yielding 194 animals for the study. The main reasons for exclusion were subclinical mastitis or clinical mastitis without generalized symptoms. Cows were approximately evenly distributed between the homeopathic $(\mathrm{n}=87)$ and placebo $(\mathrm{n}=107)$ groups. Due to severe clinical signs, $16 \%$ of animals $(32 / 194)$ were removed from the study [homeopathic treatment $20 \%$ (17/87); placebo $14 \%$ (15/107); $P=$ 0.303], leaving 70 animals in the homeopathic group and 92 in the placebo group for the final statistical analysis.

\section{Descriptive Data}

Among all groups, 38\% (62/162) of animals were in their first lactation. Overall, 80\% (129/161) of cows had not had clinical mastitis in their previous lactation, and in $92 \%(148 / 161)$ of cases, only 1 quarter was affected. Overall, $42 \%$ (61/145), 3\% (5/145), and 16\% (23/145) of animals were positive for Streptococcus uberis, Staph. aureus, and E. coli, respectively. The 305-d milk yield in the previous lactation averaged between $11,237 \mathrm{~kg}$ [interquartile range (IQR) 9,767 to 12,066$]$ and $10,667 \mathrm{~kg}$ (IQR 9,681 to 11,811) for the homeopathic and placebo groups, respectively $(P=0.299)$. We observed no differences between groups with respect to milk yield in the previous lactation, disease data in the previous or current lactations, or bacteriological findings.

\section{Treatment}

The median treatment time was $5 \mathrm{~d}$ in both groups and was not significantly different $(P=0.683)$ between groups (Figure 2). Similarly, when considering only animals without allopathic treatments, survival analysis showed no differences between groups (homeopathic treatment: $\mathrm{n}=20,5$ d; placebo: $\mathrm{n}=34,5 \mathrm{~d} ; P=0.775$; data not shown). The median number of homeopathic or placebo treatments over all treatment days was 17 times per animal per group $(P=0.771)$. Between $66 \%$ (46/70; homeopathic treatment) and $60 \%$ (55/92; placebo) of cows received non-antibiotic allopathic treatments (Table 4; $P=0.440$ ). Antibiotic treatments were given to $61 \%(56 / 92)$ and $70 \%(49 / 70)$ of animals in the placebo and homeopathic groups, respectively $(P$ $=0.228)$. We observed no side effects from the homeopathic treatment.

\section{Mastitis Cure}

The median disease duration was not significantly different between treatment groups and lasted between $5 \mathrm{~d}$ (placebo) and $6 \mathrm{~d}$ (homeopathic therapy; $P=$ 0.987). Survival function (Figure 3 ) showed the similarity of the results between groups. Likewise, survival analysis that included only animals without allopathic treatments showed no differences between groups (homeopathic treatment: $\mathrm{n}=20,5$ d; placebo: $\mathrm{n}=34,5 \mathrm{~d}$; $P=0.555$; data not shown).

We observed no significant differences in cure risk between treatments: $7 \mathrm{~d}$ after disease occurrence, $76 \%$ of both the homeopathic group (53/70) and the placebo group (70/92) were clinically cured $(P=0.956$, Table 4). At $14 \mathrm{~d}$ after disease occurrence, $89 \%(62 / 70)$ of the homeopathy group and $87 \%$ (80/92) of the placebo group were clinically cured $(P=0.757)$.

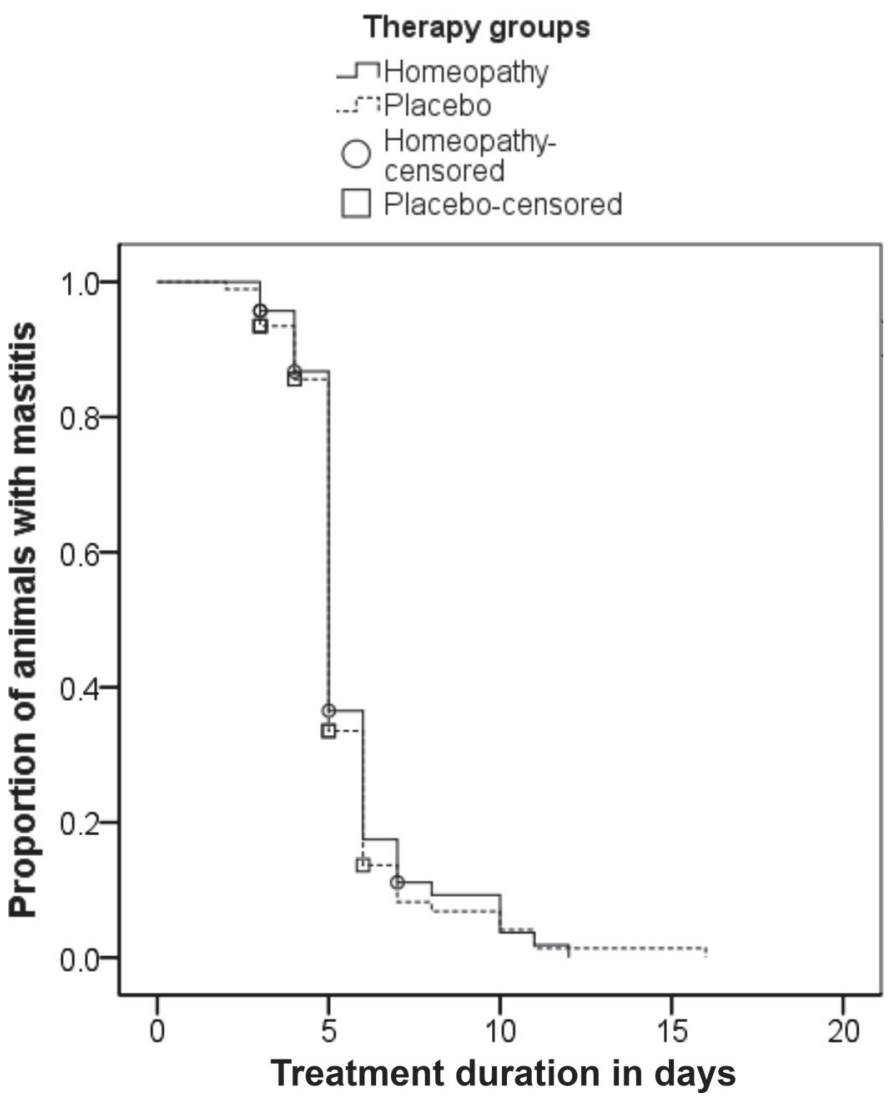

Figure 2. Kaplan-Meier survival function for treatment duration in cows that received homeopathy or placebo treatment; cows were censored if they were culled before the end of treatment. 


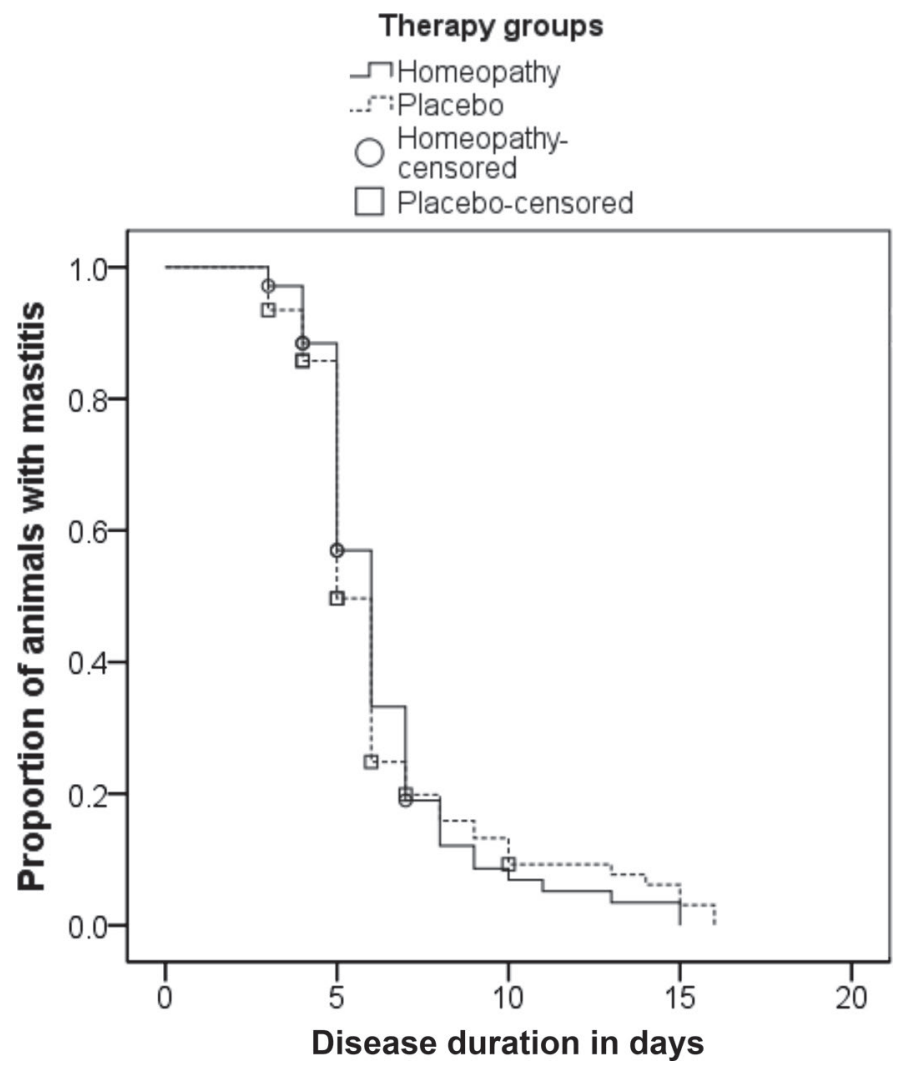

Figure 3. Kaplan-Meier survival function for disease duration in cows that received homeopathy or placebo treatment; cows were censored if they were culled before mastitis was cured.

\section{Follow-Up Period}

Milk yield at first milk recording after clinical cure was $35.5 \mathrm{~kg} / \mathrm{d}$ (IQR 29.5 to 42.2 ) and $33.4 \mathrm{~kg} / \mathrm{d}$ $(\mathrm{IQR}=30.7$ to 40.2$)$ for the homeopathic and placebo groups, respectively $(P=0.748)$. Similarly, milk SCC at first milk recording were 74,000 cells $/ \mathrm{mL}$ (IQR 46,000 to 294,000) and 71,000 cells/mL (IQR $35,000$ to 293,000$)$ at a median of 15 and $19 \mathrm{~d}$ after the last day of disease for the homeopathic and placebo groups, respectively $(P=0.389)$.
On average across both treatment groups, $23 \%$ of animals were identified with clinical mastitis during the $200 \mathrm{~d}$ period following clinical cure, and we observed no differences between groups $(P=0.702$, Table 4$)$.

Between $32 \%$ (29/92) of the placebo group and 39\% $(27 / 70)$ of the homeopathy group left the farm within the disease or follow-up period $(P=0.350)$. Fourteen animals were sold for breeding purposes (homeopathic treatment: $10 \%, 7 / 70$; placebo: $8 \%, 7 / 92)$, and 42 were sent for slaughter or euthanized (homeopathic treatment: $32 \%, 20 / 63$; placebo: $26 \%, 22 / 85)$. The proportion of cows slaughtered or euthanized (excluding those sold for breeding purposes) was not different among groups $(P=0.434)$.

\section{DISCUSSION}

Compared with other farms in the same state, the study farm had superior performance and udder health parameters. In 2013, the average milk yield reported for other farms was $9,277 \mathrm{~kg} / 305$-d lactation and SCC averaged 285,000 cells $/ \mathrm{mL}$ (Landeskontrollverband Berlin-Brandenburg, 2014). The study farm was a wellmanaged farm, and biases due to poor udder health management, reinfection, or high prevalence of contagious pathogens were unlikely.

Random allocation of study participants is necessary to draw causal inferences from a clinical study (Kunz and Oxman, 1998). Hektoen et al. (2004) used blocked randomization to balance participant numbers among groups. In the current study, we achieved randomization by allocating cows based on the last digit of their ear tag. This resulted in unequal numbers of cows in the study groups. However, the absence of statistical differences between groups in basic parameters from the previous lactation indicated that randomization was successful and yielded homogeneous groups. Therefore, a comparison between groups was valid.

To reduce bias in subjective assessments, blinding is essential for clinical trials (Schulz et al., 1995; Jadad et al., 1996). On the other hand, some authors report

Table 4. Treatment, mastitis cure, and culling of study animals

\begin{tabular}{|c|c|c|c|c|c|}
\hline \multirow[b]{2}{*}{ Parameter } & \multicolumn{2}{|c|}{$\begin{array}{l}\text { Homeopathy } \\
\quad(\mathrm{n}=70)\end{array}$} & \multicolumn{2}{|c|}{$\begin{array}{l}\text { Placebo } \\
(\mathrm{n}=92)\end{array}$} & \multirow[b]{2}{*}{$P$-value } \\
\hline & No. & $\%$ & No. & $\%$ & \\
\hline Non-antibiotic allopathic treatment & 46 & 65.7 & 55 & 59.8 & 0.440 \\
\hline Antibiotic treatment & 49 & 70.0 & 56 & 60.9 & 0.228 \\
\hline Allopathic treatment (antibiotic or non-antibiotic) & 50 & 71.4 & 58 & 63.0 & 0.262 \\
\hline Mastitis cure within $7 \mathrm{~d}$ & 53 & 75.7 & 70 & 76.1 & 0.956 \\
\hline Mastitis cure within $14 \mathrm{~d}$ & 62 & 88.6 & 80 & 87.0 & 0.757 \\
\hline Follow-up mastitis within $200 \mathrm{~d}$ after clinical cure & 17 & 24.3 & 20 & 21.7 & 0.702 \\
\hline Culled within $200 \mathrm{~d}$ after clinical cure & 27 & 38.6 & 29 & 31.5 & 0.350 \\
\hline
\end{tabular}


that double or even triple blinding is incompatible with the individualized treatments of classical homeopathy (Hektoen, 2005). The present study was triple-blinded (i.e., animal caretaker, veterinarian, statistical analysis), reducing the risk of biases. Nevertheless, because we used placebo preparations for each of the homeopathic remedies, individualized allocation of treatments for each cow was possible. Moreover, a change of homeopathic or placebo remedy was possible within the group assignment if clinical improvement was delayed. However, due to the use of different remedies and combinations of remedies, it was not possible to assess the efficacy of a single remedy; instead, we assessed the practical treatment combination commonly used on conventional dairy farms.

The study used clinical homeopathy, which is more practical for use on larger farms than classical homeopathy. Classical homeopathy emphasizes a holistic view of the patient and the disease. It is important to take the patient's exact history and to examine, assess, and treat the patient accurately and individually. It is possible, depending on the symptoms shown, that 2 patients with the same academic medical diagnosis would be treated with different homeopathic remedies (Hektoen, 2005). In clinical homeopathy, finding the right treatment is based mainly on symptoms related to the affected organ system. Moreover, several homeopathic remedies can be combined that support the effects of the others. Large herds, loose housing, and the lack of intensive observation of individuals make classical homeopathy challenging for large-animal veterinary medicine. The principles of clinical homeopathy are considerably more favorable for large herds (Day, 1986; King, 1992).

In this study, median time to clinical recovery ranged from 5 to $6 \mathrm{~d}$ for both groups. This time was shorter than previously reported for homeopathic therapy. In a previous study, the time to clinical recovery for cows in the homeopathy group was up to $10 \mathrm{~d}$ (Boldyreva, 2003). In another study, cows treated with homeopathy needed $7.7 \mathrm{~d}$ to achieve clinical and cytological cure, and cows treated with intramammary antibiotics reached clinical and cytological cure after $4.5 \mathrm{~d}$ (Varshney and Naresh, 2005). The short duration to clinical cure in the present study might have been due to the additional allopathic therapies offered when necessary and the strict exclusion criteria. However, the time to recovery was longer than reported for antibiotic mastitis therapy only (Varshney and Naresh, 2005).

In the present study, 75 to $80 \%$ of animals were clinically cured on d 7 after disease occurrence. In other studies, the cure risk ranged from $51 \%$ on d 14 to 21 after clinical cure (Garbe, 2003) to $78 \%$ on d 7 (Merck et al., 2004). The clinical cure risk was relatively high in the present study; however, the literature reported different time intervals for assessment, making a comparison difficult. We assessed clinical cure in the present study based on subjective criteria such as normal general appearance, absence of clinical symptoms, and physiological milk quality as described by the European Medicines Agency (2013). Other studies divided diagnostic findings between visual milk quality and palpation of the udder (Werner et al., 2010), a combination of the 2 (Merck et al., 2004; Varshney and Naresh, 2005; Walkenhorst, 2006), or one or the other (Hillerton and Kliem, 2002; Roberson et al., 2004). To avoid bias in the assessment of subjective criteria, blinding of animal caretakers and veterinarians was performed. This study did not assess bacteriological cure or cytological cure at the quarter level, because it was not possible to sample cows at specific times after clinical cure. We approximated cytological cure by using individual cow SCC at milk recording after clinical cure. However, due to the different periods between clinical cure and milk recording for each cow, this measure may have been less precise than cytological control at certain days after clinical cure. Nevertheless, we observed no differences between groups in the present study. Future studies should include bacteriological and cytological cure at specified days after clinical cure to increase diagnostic precision.

We used 162 animals for the statistical analysis. With at least 70 animals each in the homeopathy and placebo groups, it would have been possible to detect a biologically meaningful difference in disease duration of $2 \mathrm{~d}[\mathrm{SD}=2.34$ (homeopathy) and $\mathrm{SD}=2.78$ (placebo); power $=99.6 \%$ ] using a formula described previously (Kutschmann et al., 2006). Therefore, the power of this study was sufficient to test the main hypothesis with a relevant difference between groups. Because we used strict scientific methods, including blinding, randomization, and placebo control, bias was reduced and the results can be extrapolated to other dairy farms in Germany.

This blinded, randomized clinical trial for homeopathic mastitis treatments did not show differences in clinical cure rate, disease duration, milk yield, or SCC after clinical cure between placebo and homeopathic treatments, indicating that a specific treatment effect was not present for homeopathic remedies for mastitis. This result was in agreement with findings from Hektoen et al. (2004) and Werner et al. (2010). However, other researchers reported better results in the control group (allopathic treatments) than in the homeopathic group (Garbe et al., 2000; Varshney and Naresh, 2005; Walkenhorst, 2006). This difference was likely because 
an allopathic control group was used rather than a placebo control. In the present study, we used homeopathic preparations with a potentization of C200. Based on chemical principles (Avogadro constant), it would be impossible to detect a molecule of active substance in this remedy. Therefore, the homeopathic and placebo globules were chemically indistinguishable.

Most often, previous studies did not use allopathic drugs in the homeopathic group and compared homeopathic treatments to allopathic treatments (Garbe et al., 2000; Varshney and Naresh, 2005; Walkenhorst, 2006). In the present study, allopathic treatments (e.g., antibiotics or anti-inflammatory drugs) were available for animals in both groups. We did this to ensure animal welfare by providing proven and effective treatments when necessary and because it resembled common practice on farms that used homeopathic remedies (Hektoen, 2004). Additionally, we were able to measure the use of allopathic drugs among groups. We found that homeopathic treatments could not prevent the use of allopathic drugs on the study farm. However, one might hypothesize that farms using homeopathic remedies would generally use fewer allopathic drugs (Merck et al., 2004) because of the longer time allowance for self-cure before allopathic treatments were given (Vaarst et al., 2006). Self-cure in other studies was $>60 \%$ (Wilson et al., 1999). Withholding allopathic treatment for $1 \mathrm{~d}$ in mild cases of clinical mastitis might reduce antibiotic use on the farm. Moreover, farmers tend to use homeopathy to reduce the use of antibiotic therapies (Hektoen, 2004). The results of a recent observational study in Belgium indicated that such an effect could be present (Stevens et al., 2016). The duration of homeopathic therapy might also be used for bacteriological assessment of mastitis samples to choose an appropriate antibiotic treatment in case self-cure does not occur. Mansion-de Vries et al. (2015) recommended selection of an effective narrowspectrum antibiotic treatment based on microbiological information. In this way, homeopathy could be seen as a management tool rather than an effective therapy (McMillan, 1999; Hektoen, 2005). Further research is necessary comparing antibiotic usage on farms that use homeopathic remedies and those that do not.

As detailed above, the limitations of this blinded, randomized, placebo-controlled study were the use of non-standardized allopathic treatments in the homeopathic and placebo groups, the narrow case definition excluding mild clinical mastitis cases, the lack of bacteriological and cytological information for the assessment of cure, and the fact that the study was conducted on a single farm.

The main goal of this study was to assess the use of homeopathy in farm animal veterinary medicine. Mas- titis is one of the most common herd health problems, and it was selected to achieve sufficient sample size with similarly diseased animals. The included animals served as models for assessing the effect of homeopathy compared with placebo. To avoid unnecessary stress and harm for the animals, allopathic treatments were given when necessary based on clinical symptoms. Analysis showed that allopathic treatments were distributed evenly between the groups. This study found that homeopathic treatment had no additional effect when used to treat mastitis with mild generalized symptoms. However, homeopathic remedies could be used in certain situations on farms for selected diseases with high self-cure rates, not as a therapy but as a management tool. Future studies should assess the use of homeopathic remedies for diseases with high selfcure rates. In these cases, homeopathic remedies could help to provide additional time to allow the animal to self-cure and avoid unnecessary allopathic (especially antibiotic) treatments. In any case, self-cure should be supported by improvements to the environment. For diseases in which self-cure is less likely (e.g., dystocia, hypocalcemia, severe clinical mastitis), homeopathic treatments are not recommended. The decision for or against homeopathic treatments should be based on the scientifically assessed likelihood of self-cure. Nevertheless, for most diseases, research on self-cure is lacking, leaving decisions about the use of homeopathic treatments with the herd veterinarian. Future studies should provide a basis for these decisions. Blinded, randomized, placebo-controlled trials are necessary to quantify self-cure in important cattle diseases and investigate the effect of homeopathic treatments (e.g. potential reduction of antibiotic treatments) on various diseases with high self-cure rates.

\section{CONCLUSIONS}

We observed no significant differences between the homeopathic and placebo groups in terms of time to clinical cure, clinical cure risk, SCC after mastitis cure, or mastitis recurrence risk, indicating that specific pharmacological effects were not present. Homeopathic treatments did not appear to have an additional effect on clinical mastitis with mild generalized symptoms in dairy cows, and their use should be carefully reassessed on each farm.

\section{ACKNOWLEDGMENTS}

The authors declare no conflicts of interest. Special thanks go to the participating farm personnel for their help in conducting this study. 


\section{REFERENCES}

Albrecht, H. 2013. Zur Lage der Komplementärmedizin in Deutschland. Forsch. Komplement. Med. 20:73-77. [In German]

Boldyreva, E. M. 2003. Mastitis of cows and the use of homeopathy for the treatment. Page 278 in Proc. 54th Eur. Assoc. for Animal Production Annual Mtg., Rome, Italy. Eur. Assoc. Anim. Prod, Rome, Italy.

Bramley, A. J., and F. H. Dodd. 1984. Reviews of the progress of dairy science: Mastitis control-progress and prospects. J. Dairy Res. $51: 481-512$.

Busato, A., P. Trachsel, M. Schällibaum, and J. W. Blum. 2000. Udder health and risk factors for subclinical mastitis in organic dairy farms in Switzerland. Prev. Vet. Med. 44:205-220.

Clausen, J., H. Albrecht, and R. T. Mathie. 2013. Veterinary clinical research database for homeopathy: Placebo-controlled trials. Complement. Ther. Med. 21:115-120.

Craven, N. 1987. Efficacy and financial value of antibiotic treatment of bovine clinical mastitis during lactation-A review. Br. Vet. J. 143:410-422

Day, C. 1986. Clinical trials in bovine mastitis: Use of nosodes for prevention. Br. Homeopath. J. 75:11-14.

Day, C., and A. Schmidt. 2008. Gesunde Rinderbestände durch Homöopathie: Aufzucht, Haltung und Behandlung. 3rd ed. Sonntag Verlag, Stuttgart, Germany. [In German]

Deutsche Veterinärmedizinische Gesellschaft. 2009. Leitlinien-Entnahme von Milchproben unter antiseptischen Bedingungen und Isolierung und Identifizierung von Mastitiserregern. Vol. 2. Verlag der DVG Service GmbH, Giessen, Germany. [In German]

Deutsche Veterinärmedizinische Gesellschaft. 2012. LeitlinienBekämpfung der Mastitis des Rindes als Bestandsproblem. Vol. 5. Fachgruppe Milchhygiene Sachverständigenausschuss Subklinische Mastitis. Verlag der DVG Service GmbH, Giessen, Germany. [In German]

Dirksen, G., H.-D. Gründer, M. Stöber, and G. Rosenberger. 2012. Die klinische Untersuchung des Rindes. Enke, Berlin, Germany. [In German]

Ehinger, A. M., and M. Kietzmann. 1998. [Pharmacokinetic aspects of mastitis therapy]. Berl. Munch. Tierarztl. Wochenschr. 111:337343. [In German; English abstract]

Enbergs, H. 1998. Homeopathy. Compounds for the prevention of ovarian dysfunction. Milchpraxis 36:5-8.

Erskine, R. J., P. C. Bartlett, S. R. Tavernier, L. H. Fowler, R. D. Walker, J. H. Seguin, and D. Shuster. 1998. Recombinant bovine interleukin-2 and dry cow therapy: Efficacy to cure and prevent intramammary infections, safety, and effect on gestation. J. Dairy Sci. 81:107-115.

European Commission. 2008. Commission Regulation (EC) No $889 / 2008$ of 5 September 2008 laying down detailed rules for the implementation of Council Regulation (EC) No 834/2007 on organic production and labelling of organic products with regard to organic production, labelling and control Pages 1-84 in Official Journal of the European Union Vol. L 250.

European Medicines Agency. 2013. Guideline on the conduct of efficacy studies for intramammary products for use in cattle. European Medicines Agency, London, UK.

Fitzpatrick, C. E., N. Chapinal, C. S. Petersson-Wolfe, T. J. DeVries, D. F. Kelton, T. F. Duffield, and K. E. Leslie. 2013. The effect of meloxicam on pain sensitivity, rumination time, and clinical signs in dairy cows with endotoxin-induced clinical mastitis. J. Dairy Sci. 96:2847-2856.

Garbe, S. 2003. Untersuchungen zur Verbesserung der Eutergesundheit bei Milchkühen unter besonderer Berücksichtigung des Einsatzes von Homöopathika. Tierklinik für Fortpflanzung des Fachbereiches Veterinärmedizin. Dissertation. Freie Universität Berlin, Germany.

Garbe, S., P. Klocke, J. Spranger, and C. C. Merck. 2000. Therapy of clinical mastitis by homeopathic medication. Reprod. Domest. Anim. 35:17-18

Gnadl, B. 2011. Ansätze der homöopathischen Behandlung des Rindes. Pages 32-36 in Klassische Homöopathie für Rinder. Vol. 4. Eigenverlag Baumgartner, Übersee/Feldwies, Germany. [In German]
Grommers, F. J., D. d. Geer, and C. A. t. Veen. 1985. Duration of bovine intramammary infections in commercial dairy herds. Vet. Rec. 116:581-584.

Hahnemann, S. 1810. Organon der rationellen Heilkunde. Vol. 1. Arnold, Dresden, Germany. [In German]

Hektoen, L. 2004. Investigations of the motivation underlying Norwegian dairy farmers' use of homoeopathy. Vet. Rec. 155:701-707.

Hektoen, L. 2005. Review of the current involvement of homeopathy in veterinary practice and research. Vet. Rec. 157:224-229.

Hektoen, L., S. Larsen, S. A. Odegaard, and T. Loken. 2004. Comparison of homeopathy, placebo and antibiotic treatment of clinical mastitis in dairy cows - Methodological issues and results from a randomized-clinical trial. J. Vet. Med. A Physiol. Pathol. Clin. Med. 51:439-446.

Hillerton, J. E., and K. E. Kliem. 2002. Effective treatment of Streptococcus uberis clinical mastitis to minimize the use of antibiotics. J. Dairy Sci. 85:1009-1014.

Hogan, J. S., K. L. Smith, D. A. Todhunter, and P. S. Schoenberger 1992. Field trial to determine efficacy of an Escherichia coli J5 mastitis vaccine. J. Dairy Sci. 75:78-84

Hortet, P., and H. Seegers. 1998. Loss in milk yield and related composition changes resulting from clinical mastitis in dairy cows. Prev. Vet. Med. 37:1-20.

Houben, E. H., A. A. Dijkhuizen, J. A. v. Arendonk, and R. B. Huirne. 1993. Short- and long-term production losses and repeatability of clinical mastitis in dairy cattle. J. Dairy Sci. 76:2561-2578.

Hovi, M., and S. Roderick. 2000. Mastitis and mastitis control strategies in organic milk. Cattle Pract. 8:259-264.

Institute of Medicine of the National Academies. 2005. Complementary and Alternative Medicine in the United States. Committee on the Use of Complementary and Alternative Medicine by the American Public, National Academy of Sciences, Washington, DC.

Jadad, A. R., R. A. Moore, D. Carroll, C. Jenkinson, D. J. Reynolds, D. J. Gavaghan, and H. J. McQuay. 1996. Assessing the quality of reports of randomized clinical trials: Is blinding necessary? Control. Clin. Trials 17:1-12.

King, G. 1992. Veterinärhomöopathie: Einführung und Materia medica. Schlütersche Verlagsgesellschaft, Hanover, Germany. [In German]

Kossaibati, M. A., and R. J. Esslemont. 1997. The costs of production diseases in dairy herds in England. Vet. J. 154:41-51.

Kunz, R., and A. D. Oxman. 1998. The unpredictability paradox: Review of empirical comparisons of randomised and non-randomised clinical trials. BMJ 317:1185-1190.

Kutschmann, M., R. Bender, U. Grouven, and G. Berg. 2006. [Aspects of sample size determination and power calculation illustrated on examples from rehabilitation research]. Rehabilitation (Stuttg.) 45:377-384. [In German; English abstract]

Landeskontrollverband Berlin-Brandenburg. 2014. Jahresbericht 2014 Landeskontrollverband Berlin-Brandenburg e.V., Waldsieversdorf, Germany.

Langford, F. M., K. M. Rutherford, M. C. Jack, L. Sherwood, A. B. Lawrence, and M. J. Haskell. 2009. A comparison of management practices, farmer-perceived disease incidence and winter housing on organic and non-organic dairy farms in the UK. J. Dairy Res. 76:6-14.

Lewith, G. T., E. Ernst, S. Mills, P. Fisher, J. Monckton, D. Reilly, D. Peters, and K. Thomas. 2000. Complementary medicine must be research led and evidence based. BMJ 320:188.

Linder, M., J. H. Paduch, A. S. Grieger, E. M.-d. Vries, N. Knorr, C. Zinke, K. Teich, and V. Krömker. 2013. [Cure rates of chronic subclinical Staphylococcus aureus mastitis in lactating dairy cows after antibiotic therapy]. Berl. Munch. Tierarztl. Wochenschr. 126:291-296. [In German; English abstract]

Löscher, W., and A. Richter. 2010. Homöopathika. Pages 467-498 in Pharmakotherapie bei Haus- und Nutztieren. 8th ed. W. Löscher, F. R. Ungemach, and R. Kroker, ed. Enke Verlag, Stuttgart, Germany.

Löscher, W., F. R. Ungemach, and R. Kroker. 2006. Pharmakotherapie bei Haus- und Nutztieren. Parey, Berlin, Germany. 
Lührmann, B. 2007. Was kostet eine Mastitis? Milchpraxis 45:48-52. [In German]

Mac Leod, G., and H. Wolter. 2006. Homöopathische Behandlung der Rinderkrankheiten. Sonntag Verlag, Stuttgart, Germany.

Mansion-de Vries, E. M., M. Hoedemaker, and V. Kromker. 2015. [Evidence-based aspects of clinical mastitis treatment]. Tierarztl. Prax. Ausg. G Grosstiere Nutztiere 43:287-295. [In German; English abstract]

Mathie, R. T., and J. Clausen. 2014. Veterinary homeopathy: Systematic review of medical conditions studied by randomised placebocontrolled trials. Vet. Rec. 175:373-381.

Mathie, R. T., and J. Clausen. 2015. Veterinary homeopathy: Meta-analysis of randomised placebo-controlled trials. Homeopathy 104:3-8.

McMillan, F. D. 1999. The placebo effect in animals. J. Am. Vet. Med. Assoc. 215:992-999.

Merck, C. C., C. Fidelak, P. Klocke, A. Reinecke, K. Paal, J. Rothe, and J. Spranger. 2004. Etablierung der homöopathischen Mastitistherapie in einem biologisch-dynamisch wirtschaftenden Milcherzeugerbetrieb unter Berücksichtigung ökologischer, epidemiologischer und ökonomischer Gesichtspunkte. In Abschlussbericht zum Forschungsvorhaben 99UM032. Tierklinik für Fortpflanzung, Fachbereich Veterinärmedizin, Freie Universitat Berlin, Germany. [In German]

Merck, C. C., B. Sonnenwald, and H. Rollwage. 1989. Studies in the treatment of acute bovine mastitis with homeopathic drugs. Berl. Munch. Tierarztl. Wochenschr. 102:266-272.

Mettler, W. 1991. Mastitisbehandlung von Kühen beim Einzeltier. Prakt Tierarzt XXII (Collegium veterinarium):71-72.

Olde Riekerink, R. G., H. W. Barkema, D. F. Kelton, and D. T. Scholl. 2008. Incidence rate of clinical mastitis on Canadian dairy farms. J. Dairy Sci. 91:1366-1377.

Posadzki, P., A. Alotaibi, and E. Ernst. 2012. Adverse effects of homeopathy: A systematic review of published case reports and case series. Int. J. Clin. Pract. 66:1178-1188.

Rajala-Schultz, P. J., and Y. T. Grohn. 1999. Culling of dairy cows. Part I. Effects of diseases on culling in Finnish Ayrshire cows. Prev. Vet. Med. 41:195-208.

Rajala-Schultz, P. J., Y. T. Grohn, C. E. McCulloch, and C. L. Guard 1999. Effects of clinical mastitis on milk yield in dairy cows. J. Dairy Sci. 82:1213-1220.

Rijnberk, A., and D. W. Ramey. 2007. The end of veterinary homeopathy. Aust. Vet. J. 85:513-516.

Roberson, J. R. 2012. Treatment of clinical mastitis. Vet. Clin. North Am. Food Anim. Pract. 28:271-288.
Roberson, J. R., L. D. Warnick, and G. Moore. 2004. Mild to moderate clinical mastitis: Efficacy of intramammary amoxicillin, frequent milk-out, a combined intramammary amoxicillin, and frequent milk-out treatment versus no treatment. J. Dairy Sci. 87:583-592.

Schepers, J. A., and A. A. Dijkhuizen. 1991. The economics of mastitis and mastitis control in dairy cattle: A critical analysis of estimates published since 1970. Prev. Vet. Med. 10:213-224.

Schmidt, J. M. 2008. Believing in order to understand: Hahnemann's hierarchisation of values. Homeopathy 97:156-160.

Schulz, K. F., I. Chalmers, R. J. Hayes, and D. G. Altman. 1995 Empirical evidence of bias. Dimensions of methodological quality associated with estimates of treatment effects in controlled trials. JAMA 273:408-412.

Smith, C. F. 2002. Criticisms of veterinary homeopathic practice and research. Aust. Vet. J. 80:264-266.

Stevens, M., S. Piepers, and S. De Vliegher. 2016. Mastitis prevention and control practices and mastitis treatment strategies associated with the consumption of (critically important) antimicrobials on dairy herds in Flanders, Belgium. J. Dairy Sci. 99:2896-2903.

Vaarst, M., T. W. Bennedsgaard, I. Klaas, T. B. Nissen, S. M. Thamsborg, and S. Østergaard. 2006. Development and daily management of an explicit strategy of nonuse of antimicrobial drugs in twelve Danish organic dairy herds. J. Dairy Sci. 89:1842-1853.

Varshney, J. P., and R. Naresh. 2005. Comparative efficacy of homeopathic and allopathic systems of medicine in the management of clinical mastitis of Indian dairy cows. Homeopathy 94:81-85.

Vickers, A., and C. Zollman. 1999. ABC of complementary medicine. Homoeopathy. BMJ 319:1115-1118.

Walkenhorst, M. 2006. Vergleich von homöopathischer mit antibiotischer Laktationstherapie zur Behandlung von Mastitiden des Rindes. Doctoral thesis. Klinik für Fortpflanzungsmedizin der Vetsuisse-Fakultät. Universität Zürich, Switzerland. [In German

Werner, C., A. Sobiraj, and A. Sundrum. 2010. Efficacy of homeopathic and antibiotic treatment strategies in cases of mild and moderate bovine clinical mastitis. J. Dairy Res. 77:460-467.

Wilson, D. J., R. N. Gonzalez, K. L. Case, L. L. Garrison, and Y. T. Grohn. 1999. Comparison of seven antibiotic treatments with no treatment for bacteriological efficacy against bovine mastitis pathogens. J. Dairy Sci. 82:1664-1670.

Winter, P. 2008. Praktischer Leitfaden Mastitis Vorgehen beim Einzeltier und im Bestand. Parey, Vienna, Austria. [In German]

Zoche-Golob, V., and J. Spilke. 2013. [Herd-specific estimation of milk yield reduction due to recurrent clinical mastitis]. Berl. Munch. Tierarztl. Wochenschr. 126:269-276. [In German; English abstract] 